\title{
Organizational citizenship behavior and teachers' engagement in Unified Schools of the Archdiocese of Lipa (USAL)
}

Alday, Audree $\$
Sta. Teresa College, Batangas, Philippines (audrey21483@gmail.com)

Received: 12 May 2020

Available Online: 7 July 2020
Revised: 6 June $2020 \quad$ Accepted: 22 June 2020 DOI: $10.5861 /$ ijrse.2020.5811

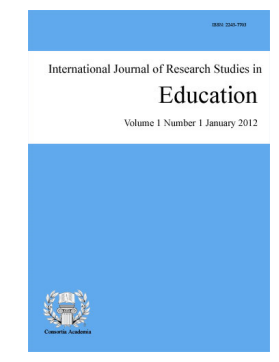

ISSN: 2243-7703 Online ISSN: 2243-7711

\section{Abstract}

In every organization, employees with organizational citizenship behavior (OCB) and work engagement become assets of the company. These two constructs greatly influence positive organizational outcomes even in the school setting. It is in this sense that the researcher was motivated to assess the teachers' OCB and engagement. It also investigated the relationship between the teachers' professional profile and organizational citizenship behavior and engagement. The study employed the descriptive correlational method with respondents of 301 teachers and 69 administrators working in Unified Schools of the Archdiocese of Lipa (USAL).Validated self-made questionnaire was administered to the respondents and their responses were tabulated, analyzed and interpreted using weighted mean and Chi-square. As a result, teachers confirmed that they possess OCB and engagement which is validated by the administrators. It also revealed that school affiliation relates to teachers OCB and engagement. Meanwhile, employment status, length of service and highest degree earned are not determinants of teachers' OCB and engagement.

Keywords: organizational citizenship behavior; employee engagement; job satisfaction; commitment; empowerment 


\section{Organizational citizenship behavior and teachers' engagement in Unified Schools of the Archdiocese of Lipa (USAL)}

\section{Introduction}

In every organization, employees with a high sense of belongingness and dedication become assets of the company. They can work for long hours and fulfill their tasks voluntarily beyond the minimum expected role behaviors. More so, they ensure effective functioning in order to achieve organizational objectives. Indeed, the aforementioned characteristics of employees would be essential, even in the school setting. In the dynamic school environment, teachers are the key persons significantly contributing to accomplishing the school's vision and mission. School administrators should ensure that their teachers have proactive behaviors for enhancing the school's ability to adapt to the different environmental changes.

With the intricacy of reform in the educational system, it is of great importance to consider the organizational citizenship behavior and engagement of teachers to respond positively to the strains of change. Organizational citizenship behavior is a voluntary behavior that is beyond the employee's formal job requirements. In school this includes giving extra attention to the needs of the students, helping fellow teachers in their personal or work-related problems and supporting the school's image and its goals. Consequently, the engagement of teachers in their work is linked to increase job satisfaction, commitment, and empowerment. Engaged teachers can work long hours and put their heart into their work. They were found to have an intrinsic motivation to perform well and meet work-related goals. More so, they are fully absorbed by and enthusiastic about their work and so takes positive action to further the school's reputation and interests.

However, high turnover and burnout are common key results when teachers do not have organizational citizenship and work engagement (Sesen, Cetin, \& Basim, 2011, Wesley \& Krishnan, 2013, and Supriadi, Ahman, Wibowo, \& Furqon, 2019). These are also the pressing problems being faced by private schools today. From the study of Buenaventura (2013), he noted that during 2010, Siena College of San Jose, School of Our Lady of Lasallette and Colegio De San Gabriel Archangel encountered pervasive teacher turnover, 56.25\%, 12\%, and $17 \%$, respectively. DepEd Secretary Leonor Briones expressed concern on the continued migration of teachers from private to public elementary and high schools while Commission on Higher Education (CHED) officer-in-charge (OIC) and spokesperson J. Prospero De Vera III said that many private Higher Education Institutions (HEIs) are losing their good faculty to State Universities and Colleges (SUCs) because they cannot keep up with the salaries being offered by the public HEIs (Malipot, 2018). Catholic Educational Association of the Philippines (CEAP) president Joel Tabora added that private schools are facing a shortage of teachers as the government continues to push for increases in the basic salary of public school teachers (Mateo, 2018). On the other hand, Dela Cruz (2016) cited that permanency or job security is higher in public than in private institutions, thus this factor is very important for private teachers or movers. Other teachers resigned because of the few benefits, unsatisfied school management and policies, few opportunities for career advancement, heavy workloads, and student discipline.

From the researcher's observation and initial interview, most of the schools under USAL also experience high turnover. USAL which stands for Unified Schools of the Archdiocese of Lipa is composed of 13 private Catholic schools located in the province of Batangas. The schools share a common vision to be a Christ-centered learning community that evangelizes the whole person to become leaders of society. For the school administrators, teacher attrition is a burden because of added recruiting, hiring and training costs. Hence, it is very vital to strengthen teachers' organizational citizenship behavior and engagement to lessen turnover and burnout. Thus, it is in this sense that the researcher was motivated to assess the teachers' organizational citizenship behavior (OCB) and engagement in the Unified Schools of the Archdiocese of Lipa.

12 Consortia Academia Publishing (A partner of Network of Professional Researchers and Educators) 


\section{Literature review}

According to Landy and Conte (2010), Organ and his colleagues labeled a type of behavior - going beyond what is expected as organizational citizenship behavior (OCB). Somech and Oplatka (2014) on the other hand defined it as an individual behavior that is discretionary, not directly or explicitly recognized by the formal reward system, and that in the aggregate promotes the effective functioning of the organization. This definition emphasizes that the behavior must be voluntary, neither role- prescribed nor part of formal job duties. For Newstrom (2015), organizational citizenship is often marked by its spontaneity, its voluntary nature, its constructive impact on results and its unexpected helpfulness or cooperativeness to others. McShane (2012) claimed that the forms of OCB could be directed toward individuals such as assisting coworkers with their work problems and adjusting work schedules to accommodate coworkers and cooperation and helpfulness toward organization such as supporting the company's public image and taking discretionary action to help the organization avoid potential problems. Moreover, Muchinsky and Culbertson (2016) termed OCB as prosocial behavior, extra-role behavior and contextual behavior. According to them, more specific factors include being conscientious and responsible, maintaining personal discipline, handling work stress, helping others and being committed to the organization. From the aforementioned concepts, the following were utilized as indicators of OCB:

$>$ Responsibility is an obligation to do something with the expectation that some action or output will result (Serrano \& Flores, 2016).

$>$ Discipline is the existence of good conduct amongst individuals (Bueno, 2016).

$>$ Managing stress in the organization involves maintaining productive levels of stress while avoiding the destructive consequences of distress (Bueno, 2016).

$>$ Helping behavior is based on two motives: altruistic and egoistic helping. Altruistic helping aims to increase another's welfare without expecting anything in return while egoistic helping wishes to increase one's own welfare (Apruebo, 2009).

Drganizational commitment is described as having strong adherence with the goals and values of the company, willingness to exert effort to achieve organizational success and having a strong desire to stay in the organization (Salansan, 2011).

Teaching, according to Farooqui (2012) is one of the most significant OCB-demanding professions. These behaviors are basically the choice of teachers to work beyond their scope of responsibilities that will contribute positively to the overall school effectiveness without expecting something in return. As cited by Gaddis (2016), the professional teacher by nature has the calling to go beyond the call of duty, doing more than what is specifically required of the position. DiPaola and Neves (2009) affirmed that teachers routinely perform behaviors directed toward helping individuals, both students and colleagues, as part of their professional identity. The organizational success might only be achieved through ensuring the OCB among the school teachers (Shrestha \& Subedi, 2020). Krastev and Stanoeva (2013) affirmed that for the school, OCB is important in the following areas: innovative approaches to training, volunteering, involvement in individual and collective extracurricular activities to promote greater responsibility, tolerance and respect in students; invest additional efforts to achieve the objectives of school cohesion in teams and more open relations in the teacher-student dyad, increased levels of school performance, which in turn leads to fully support of the positive image of the school.

Conversely, Kozlowski (2012), defined job engagement as a positive, work-related state of mind that is characterized by vigor, dedication and absorption that arises when a person experiences certain job resources such as autonomy and social support. For Noe, Hollenbeck, Gerhart, and Wright (2015), employee engagement refers to the degree to which employees are fully involved in their work and the strength of their commitment to their job and the company. Riggio (2017) stated that jobs that are high in job characteristics are more meaningful 
and more likely to engage employees. Some employees who exhibit a high degree of job satisfaction and involvement are committed to their firm's mission and have generally upbeat work moods hence, resulting in substantial employee engagement (Newstrom, 2015). Employee engagement, according to McShane (2012) is typically described as an emotional involvement in, commitment to and satisfaction with the work. Agong and Montalbo (2017) gave another concept of engagement which focuses on engagement as a management practice that interest around involvement and participation. In order to enhance work engagement, organization is advised to share employees in the process of decision making, communicate information to employees, educate employees, and use suitable reward systems (Abed \& Elewa, 2016). This means that employees should also be empowered. McShane (2012) mentioned that empowered employees view themselves as active participants in the organization, that is, their decisions and activities have an influence on the company's success. With these concepts, the researcher used the following as indicators of employee engagement:

$>$ Job satisfaction is defined as a pleasurable feeling that results from the perception that one's job fulfills or allows for the fulfillment of one's important job values (Noe et al., 2015).

$>$ Personal commitment to work simply means the total sacrifice that personnel have to make to ensure the attainment of the organization's basic objectives (Bueno, 2016).

$>$ Empowerment is any process that provides greater autonomy to employees through the sharing of relevant information and the provision of control over factors affecting job performance (Newstrom, 2015).

Consequently, teachers' roles are to improve quality of education and student development that are ready for changing (Choochom, 2016). She added that important mission requires teachers to actively invest themselves physically, emotionally, and cognitively to their work and that is to say, teachers should have work engagement. According to Qadeer, Ahmad, Hameed, and Mahmood (2016), engaged employees invest more energy in their jobs and work more enthusiastically, thus show superior in role and extra-role performance. This concept has become a core indicator that reflects the quality of teachers' occupational lives by accounting for significant variation in the prediction of their occupational and organizational outcomes, such as teaching performance, problem solving, organizational commitment, and job satisfaction (Field \& Buitendach, 2012). Socolov (2017) cited that experienced educators can intuitively recognize an engaged teacher through the following: they may think about teachers who conveyed a sense of enthusiasm for the content, they were teaching and cared deeply about the success of their students, extended themselves beyond what was minimally required, knew their subject area well but were never afraid to admit they could learn more, took pride in their work, and conveyed an infectious sense of confidence and optimism.

Several studies proposed that OCB and employee engagement result in higher levels of organizational performance and task effectiveness. Ariani (2014) mentioned that OCB has been known to improve organizational effectiveness, organizational efficiency and overall performance of the organization using the organization's social engine lubricant, reducing friction and improving efficiency. Employees who exhibit prosocial behavior are highly valued by their managers since they contribute above and beyond the normal requirements and expectations of the job (Muchinsky \& Culbertson, 2016). Thus, the importance of making organizational citizenship behaviors sensible in the entire institutions is emphasized based on the creation of a positive organizational culture in institutions, the realization of healthy organizational communication, the establishment of unity and togetherness among employees and achievement of institutional success (Avci, 2016). Meanwhile, aside from positive and fulfilling employee experience, employee engagement contributes to various positive organizational outcomes, including productivity, task and overall performance, organizational citizenship behavior and even increased client satisfaction (Green, Finkel, Fitzsimons, \& Gino, 2017). Positive relationship between employee engagement and organizational performance outcomes, staff retention, productivity, and organizations revenue were also documented (Abed \& Elewa, 2016).

With the above-mentioned benefits of OCB and work engagement, the following research questions were 
Organizational citizenship behavior and teachers' engagement in Unified Schools of the Archdiocese of Lipa

addressed:

1. What is the organizational citizenship behavior and teachers' engagement in Unified Schools of the Archdiocese of Lipa (USAL) as assessed by themselves and the administrators?

2. Is there a significant relationship between the professional profile and organizational citizenship behavior and teachers' engagement?

\section{Methodology}

\subsection{Participants}

The Unified Schools of the Archdiocese of Lipa (USAL) which is composed of 13 private catholic schools is located in the province of Batangas. These schools are classified as small, medium, and large schools from the context of the student population. From the total population of 316 teachers, the researcher used the census of 301 teachers as respondents and from the total population of 80 administrators, the researcher used the census of 69 administrators as respondents. Forty-seven percent of the teachers are regular employees while 53\% are employed as probationary. On the side of the administrators, 90\% are regular in status and $10 \%$ are under probationary. Majority of the teachers $(57 \%)$ are serving their institution for less than 5 years, $20 \%$ are with their school for 5-10 years and 7\% are employed for 16-20 years. Meanwhile, 26\% of the administrators are serving the school for 5-10 years, $20 \%$ are working for the institution below 5 years, and 17\% for 11-15 years. Out of all the teachers who participated, a vast majority of $73 \%$ graduated bachelor's degree, $18 \%$ already earned units in master's degree, $7 \%$ are master's degree holder and $2 \%$ have doctoral units. From the administrators, $1 \%$ finished the doctoral program, $4 \%$ have doctoral units, $23 \%$ graduated from the master's degree, $41 \%$ with units in the master's program and $30 \%$ are bachelors.

\subsection{Instrument}

The researcher used a self-made survey instrument in gathering data which is composed of three parts. The first part was about the teachers' professional profile which includes school affiliation, employment status, length of service, and highest educational degree earned. The second part was on teachers' organizational citizenship behavior in terms of responsibility, personal discipline, work stress, helping others, and organizational commitment. Lastly, the third part tackled the teachers' engagement in terms of job satisfaction, commitment, and empowerment. There were two sets of questionnaires, one for the teacher respondent and the other is for the administrator. The researcher used different references and materials related to the study to obtain the necessary information. The researcher also consulted 10 experts in different fields such as industrial psychology, human resource management, research, and statistics for the content and face validation of the survey questionnaire.

\subsection{Procedure}

The researcher asked permission from the President of USAL through the Vice President for Academics for the administration of the questionnaire. After receiving the president's approval, the researcher then called the 13 principals of USAL to give an overview of the study, to ask the number of teachers and administrators for the administration of the questionnaire and to set the date for the distribution of the questionnaire since the 13 schools were located in the different municipalities of Batangas. During the distribution of the questionnaire, the researcher also presented a formal letter to the principals requesting for the administration of the questionnaire. For small schools, the researcher personally explained the study and the questionnaire. After two weeks, the researcher retrieved the questionnaire from almost all of the participating schools except for those schools located on the borderline of the province. Their questionnaires were retrieved through meet-up. There was also a school that sent their answered questionnaire via LBC. 
The frequency was used to determine the number of respondents who answered the professional profile in terms of school affiliation, employment status, length of service, and highest degree earned. Rank was utilized to compare the weighted assessment of the respondents on teachers' organizational citizenship behavior and engagement. The percentage was used to express the proportion of actual respondents and the total population and frequencies of the professional profile and the total respondents in hundredths. Weighted mean was used to get the average responses on teachers' organizational citizenship behavior and engagement. Chi-square with .05 level of significance was used to determine the significant relationship between the professional profile and teachers' organizational citizenship behavior and engagement.

\section{Results}

\subsection{Organizational citizenship behavior}

Table 1 shows the means of responses to organizational citizenship behavior in terms of responsibility. Looking at the composite mean of 4.62 , both the respondents strongly agree that teachers respond to students with respect even in a difficult situation. While they agree that they demonstrate responsible self-leadership, 4.48 , assume ownership of the classroom and students' success, 4.43, dependable and ethical in special assignments given to them, 4.36 and have a sense of volunteerism for roles and tasks that are not part of their job, 4.11. Comparing the responses of the two groups of respondents, the teachers agree, with an average weighted mean of 4.38, that they demonstrate organizational citizenship behavior in terms of responsibility, while the administrators strongly agree, with an average weighted mean of 4.50. From the composite mean, both agree that they demonstrate organizational citizenship behavior in terms of responsibility with an average weighted mean of 4.40 .

\section{Table 1}

Organizational citizenship behavior in terms of responsibility

\begin{tabular}{|c|c|c|c|c|c|c|c|c|c|}
\hline \multirow{2}{*}{ Responsibility } & \multicolumn{3}{|c|}{$\mathrm{T}$} & \multicolumn{3}{|c|}{ A } & \multicolumn{3}{|c|}{$\begin{array}{l}\text { Composite } \\
\text { Mean }\end{array}$} \\
\hline & WM & DI & $\mathrm{R}$ & WM & DI & $\mathrm{R}$ & $\mathrm{CM}$ & DI & $\mathrm{R}$ \\
\hline $\begin{array}{l}\text { 1. I assume ownership of the classroom and } \\
\text { students' success. }\end{array}$ & 4.41 & A & 3 & 4.50 & $\mathrm{SA}$ & 3 & 4.43 & A & 3 \\
\hline $\begin{array}{l}\text { 2. I am dependable and ethical in special } \\
\text { assignments given to me. }\end{array}$ & 4.33 & A & 4 & 4.50 & SA & 3 & 4.36 & A & 4 \\
\hline $\begin{array}{l}\text { 3. I have a sense of volunteerism for roles and tasks } \\
\text { that are not part of my job. }\end{array}$ & 4.06 & A & 5 & 4.30 & A & 5 & 4.11 & A & 5 \\
\hline $\begin{array}{l}\text { 4. I should respond to students with respect even in } \\
\text { a difficult situation. }\end{array}$ & 4.63 & SA & 1 & 4.60 & SA & 1 & 4.62 & SA & 1 \\
\hline 5. I demonstrate responsible self-leadership. & 4.47 & A & 2 & 4.50 & SA & 3 & 4.48 & A & 2 \\
\hline Average Weighted Mean & 4.38 & A & & 4.50 & SA & & 4.40 & A & \\
\hline
\end{tabular}

Note $: \mathrm{WM}=$ Weighted Mean; DI = Descriptive Interpretation; $\mathrm{CM}=$ Composite Mean; $\mathrm{R}=\mathrm{Rank}$.

Scale range and interpretation: $4.50-5.00=$ Strongly Agree (SA); 3.50 - 4.49 = Agree (A); $2.50-3.49=$ Moderately Agree $(\mathrm{MA})$; $1.50-2.49=$ Slightly Agree (LA); $1.00-1.49=$ Disagree (D).

Table 2 shows the means of responses to organizational citizenship behavior in terms of personal discipline. The teachers and administrators strongly agree that they should keep confidential information concerning students, colleagues and the school with a composite mean of 4.79 , should maintain a professional manner at all times, 4.72, consider obeying company school rules and regulations even when no one is watching, 4.65, inspired by the school to bring out the best in them by way of job performance, 4.54 while agree on demonstrating punctuality in submitting lesson log, tests, class record and other school-related requirements, 4.30. Consequently, both groups of respondents strongly agree that teachers possess organizational citizenship behavior in terms of personal discipline with an average composite mean of 4.60. The responses of teachers obtained an average weighted mean of 4.60, while those of the administrators got 4.58. 
Organizational citizenship behavior and teachers' engagement in Unified Schools of the Archdiocese of Lipa

Table 2

Organizational citizenship behavior in terms of personal discipline

\begin{tabular}{|c|c|c|c|c|c|c|c|c|c|}
\hline \multirow{2}{*}{ Responsibility } & \multicolumn{3}{|c|}{$\mathrm{T}$} & \multicolumn{3}{|c|}{ A } & \multicolumn{3}{|c|}{$\begin{array}{l}\text { Composite } \\
\text { Mean }\end{array}$} \\
\hline & WM & DI & $\mathrm{R}$ & WM & DI & $\mathrm{R}$ & $\mathrm{CM}$ & DI & $\mathrm{R}$ \\
\hline $\begin{array}{l}\text { 1. I should maintain a professional manner at all } \\
\text { times. }\end{array}$ & 4.72 & SA & 2 & 4.72 & SA & 1.5 & 4.72 & SA & 2 \\
\hline $\begin{array}{l}\text { 2. I am inspired by the school to bring out the best } \\
\text { in me by way of job performance. }\end{array}$ & 4.54 & SA & 4 & 4.55 & SA & 3.5 & 4.54 & SA & 4 \\
\hline $\begin{array}{l}\text { 3. I consider obeying company school rules and } \\
\text { regulations even when no one is watching. }\end{array}$ & 4.65 & SA & 3 & 4.64 & SA & 3.5 & 4.65 & SA & 3 \\
\hline $\begin{array}{l}\text { 4. I am aware that I should keep confidential } \\
\text { information concerning students, colleagues and the } \\
\text { school. }\end{array}$ & 4.81 & SA & 1 & 4.72 & SA & 1.5 & 4.79 & SA & 1 \\
\hline 5. I demonstrate punctuality in submitting lesson & 4.30 & A & 5 & 4.29 & A & 5 & 4.30 & A & 5 \\
\hline Average Weighted Mean & 4.60 & SA & & 4.58 & SA & & 4.60 & SA & \\
\hline
\end{tabular}

Table 3 shows the means of responses to, organizational citizenship behavior in terms of work stress. Looking at the composite mean, both of the respondents agree that they are able to adjust to the physical working environment (heating, lighting, space, equipment, etc.) with a composite mean of 4.42, think that their skills, knowledge, and experience match the requirements of their job, 4.41, that they can cope with the challenges placed on them and the organization, 4.40, feel enthusiastic and excited every day at work, 4.17 and that they can continue teaching beyond their scheduled teaching hours, 4.16. From a holistic perspective, both the teachers and administrators agree in assessing the teachers' organizational citizenship behavior in terms of work stress with an average composite mean of 4.31 . The teachers' responses obtained an average weighted mean of 4.30 , while those of the administrators garnered a higher 4.39 .

Table 3

Organizational citizenship behavior in terms of work stress

\begin{tabular}{|c|c|c|c|c|c|c|c|c|c|}
\hline \multirow{2}{*}{ Responsibility } & \multicolumn{3}{|c|}{$\mathrm{T}$} & \multicolumn{3}{|c|}{ A } & \multicolumn{3}{|c|}{$\begin{array}{l}\text { Composite } \\
\text { Mean }\end{array}$} \\
\hline & WM & DI & $\mathrm{R}$ & WM & DI & $\mathrm{R}$ & $\mathrm{CM}$ & DI & $\mathrm{R}$ \\
\hline 1. I feel enthusiastic and excited every day at work. & 4.15 & A & 4 & 4.28 & A & 4.5 & 4.17 & A & 4 \\
\hline $\begin{array}{l}\text { 2. I can continue teaching beyond my scheduled } \\
\text { teaching hours. }\end{array}$ & 4.13 & A & 5 & 4.29 & A & 4.5 & 4.16 & A & 5 \\
\hline $\begin{array}{l}\text { 3. I think that my skills, knowledge, and experience } \\
\text { match the requirements of my job. }\end{array}$ & 4.42 & A & 1 & 4.38 & A & 3 & 4.41 & A & 2 \\
\hline $\begin{array}{l}\text { 4. I am able to adjust to the physical working } \\
\text { environment (heating, lighting, space, equipment, } \\
\text { etc.). }\end{array}$ & 4.41 & A & 2 & 4.48 & SA & 1.5 & 4.42 & A & 1 \\
\hline $\begin{array}{l}\text { 5. I can cope with the challenges placed on me and } \\
\text { the organization. }\end{array}$ & 4.37 & A & 3 & 4.54 & SA & 1.5 & 4.40 & A & 3 \\
\hline Average Weighted Mean & 4.30 & A & & 4.39 & A & & 4.31 & A & \\
\hline
\end{tabular}

Table 4 shows the means of responses to organizational citizenship behavior in terms of helping others. Looking at the composite mean of 4.59 , both of the respondents strongly agree that they are willing to help others who have work-related and personal problems ranked 1. Ranked 2.5, happy to advise, coach, or mentor a co-worker and pleasure to share with their colleagues' materials that they prepared for their class, 4.58. On the other hand, both of the respondents agree that they are eager to orient new colleagues even though it is not required, ranked 4 with a composite mean of 4.38 , and inspired to give free tutorials or remedial activities, ranked 5 with a composite mean of 4.37 . With the garnered average composite mean of 4.48 , both of the respondents agree on the indicators of organizational citizenship behavior in terms of helping others. Comparing the responses of the two groups of respondents, the teachers agree, with a weighted mean of 4.47, while the administrators strongly agree, with a weighted mean of 4.52 , on the teachers' organizational citizenship behavior in terms of helping others. 
Alday, A.

Table 4

Organizational citizenship behavior in terms of helping others

\begin{tabular}{|c|c|c|c|c|c|c|c|c|c|}
\hline \multirow[t]{2}{*}{ Responsibility } & \multicolumn{3}{|c|}{$\mathrm{T}$} & \multicolumn{3}{|c|}{ A } & \multicolumn{3}{|c|}{$\begin{array}{l}\text { Composite } \\
\text { Mean }\end{array}$} \\
\hline & WM & DI & $\mathrm{R}$ & WM & DI & $\mathrm{R}$ & $\mathrm{CM}$ & DI & $\mathrm{R}$ \\
\hline $\begin{array}{l}\text { 1. I am happy to advise, coach, or mentor a } \\
\text { co-worker. }\end{array}$ & 4.58 & SA & 3 & 4.59 & SA & 1.5 & 4.58 & SA & 2.5 \\
\hline $\begin{array}{l}\text { 2. It is my pleasure to share with my colleagues' } \\
\text { materials that I prepared for my class. }\end{array}$ & 4.59 & SA & 1.5 & 4.54 & SA & 3.5 & 4.58 & SA & 2.5 \\
\hline $\begin{array}{l}\text { 3. I am inspired to give free tutorials or remedial } \\
\text { activities. }\end{array}$ & 4.24 & A & 5 & 4.41 & A & 5 & 4.27 & A & 5 \\
\hline $\begin{array}{l}\text { 4. I am willing to help others who have } \\
\text { work-related and personal problems. }\end{array}$ & 4.59 & SA & 1.5 & 4.58 & SA & 1.5 & 4.59 & SA & 1 \\
\hline $\begin{array}{l}\text { 5. I am eager to orient new colleagues even though } \\
\text { it is not required. }\end{array}$ & 4.36 & A & 4 & 4.48 & SA & 3.5 & 4.38 & A & 4 \\
\hline Average Weighted Mean & 4.47 & A & & 4.52 & SA & & 4.48 & A & \\
\hline
\end{tabular}

Table 5 shows the means of responses to organizational citizenship behavior in terms of organizational commitment. From the composite mean, it can be gleaned that both of the respondents strongly agree that they are proud to tell others that they are part of this organization with 4.68 composites mean, extremely glad that they chose the school to work for over others they were considering before, 4.56 and willing to put in a great deal of effort beyond what is normally expected in order to help the school to be successful, 4.55. Conversely, both of the respondents agree that they accept almost any type of job assignment in order to keep working for the school with a composite mean of 4.17 and see themselves retiring in this school, 3.72. Responses of teachers and administrators are very much parallel, as they both agree on the indicators of the teachers' organizational citizenship behavior in terms of work commitment with an average composite mean of 4.34. The teachers' responses obtained an average weighted mean of 4.33 , while that of the administrators got 4.34 .

Table 5

Organizational citizenship behavior in terms of organizational commitment

\begin{tabular}{|c|c|c|c|c|c|c|c|c|c|}
\hline \multirow[t]{2}{*}{ Responsibility } & \multicolumn{3}{|c|}{$\mathrm{T}$} & \multicolumn{3}{|c|}{ A } & \multicolumn{3}{|c|}{$\begin{array}{l}\text { Composite } \\
\text { Mean }\end{array}$} \\
\hline & WM & DI & $\mathrm{R}$ & WM & DI & $\mathrm{R}$ & $\mathrm{CM}$ & DI & $\mathrm{R}$ \\
\hline $\begin{array}{l}\text { 1. I am extremely glad that I chose my school to } \\
\text { work for over others I was considering before. }\end{array}$ & 4.57 & SA & 2.5 & 4.52 & SA & 2 & 4.56 & SA & 2 \\
\hline $\begin{array}{l}2 . \text { I am willing to put in a great deal of effort } \\
\text { beyond what is normally expected in order to help } \\
\text { the school to be successful. }\end{array}$ & 4.57 & SA & 2.5 & 4.43 & A & 3 & 4.55 & SA & 3 \\
\hline $\begin{array}{l}\text { 3. I would accept almost any type of job assignment } \\
\text { in order to keep working for the school. }\end{array}$ & 4.2 & A & 4 & 4.06 & A & 4 & 4.17 & A & 4 \\
\hline 4. I can see myself retiring in this school. & 3.65 & A & 5 & 4.03 & A & 5 & 3.72 & A & 5 \\
\hline 5. I am proud to tell others that I am part of this & 4.67 & SA & 1 & 4.68 & SA & 1 & 4.68 & SA & 1 \\
\hline Average Weighted Mean & 4.33 & A & & 4.34 & A & & 4.34 & A & \\
\hline
\end{tabular}

\subsection{Teachers' engagement}

Table 6 shows the means of responses to teachers' engagement in terms of job satisfaction. The composite mean shows that both of the respondents strongly agree that teachers listen attentively to student problems, comments and concerns with a composite mean of 4.60, ranked first, build a good working relationship with their colleagues, 4.56, ranked second and give their full support to the school administrators, 4.53, ranked third. However, both of the respondents agree that teachers pay a lot of attention to their work with a composite mean of 4.46, maintain their attendance at work above the norm, 4.44 and display dedication to their career by maximizing their performance and productivity, 4.41, ranked 5, 6 and 7 respectively. Also, both of the respondents agree that teachers are always energetic and enthusiastic in class, with a composite mean of 4.34, schedule student conference and/or parent conference, 4.32, always persevere even when things do not go well,

18 Consortia Academia Publishing (A partner of Network of Professional Researchers and Educators) 
Organizational citizenship behavior and teachers' engagement in Unified Schools of the Archdiocese of Lipa

4.30 and resilient with their work mentally and emotionally, 4.20. Comparing the responses closely, both groups agree on the indicators of teachers' engagement in terms of job satisfaction with an average composite mean of 4.42. Accordingly, teachers obtained an average weighted mean of 4.43 and the administrators with 4.37 .

Table 6

Teachers' engagement in terms of job satisfaction

\begin{tabular}{|c|c|c|c|c|c|c|c|c|c|}
\hline \multirow[t]{2}{*}{ Responsibility } & \multicolumn{3}{|c|}{$\mathrm{T}$} & \multicolumn{3}{|c|}{ A } & \multicolumn{3}{|c|}{$\begin{array}{l}\text { Composite } \\
\text { Mean }\end{array}$} \\
\hline & WM & DI & $\mathrm{R}$ & WM & DI & $\mathrm{R}$ & $\mathrm{CM}$ & DI & $\mathrm{R}$ \\
\hline $\begin{array}{l}\text { 1. I display dedication to my career by maximizing } \\
\text { my performance and productivity. }\end{array}$ & 4.41 & A & 6 & 4.43 & A & 5 & 4.41 & A & 6 \\
\hline $\begin{array}{l}\text { 2. I maintain my attendance at work above the } \\
\text { norm. }\end{array}$ & 4.44 & A & 5 & 4.43 & A & 5 & 4.44 & A & 5 \\
\hline $\begin{array}{l}\text { 3. I am resilient with my work mentally and } \\
\text { emotionally. }\end{array}$ & 4.33 & A & 8 & 3.62 & A & 10 & 4.20 & A & 10 \\
\hline $\begin{array}{l}\text { 4. I always persevere even when things do not go } \\
\text { well. }\end{array}$ & 4.28 & A & 9.5 & 4.41 & A & 8 & 4.30 & A & 9 \\
\hline $\begin{array}{l}\text { 5. I give my full support to the school } \\
\text { administrators. }\end{array}$ & 4.56 & SA & 2.5 & 4.43 & A & 5 & 4.54 & SA & 3 \\
\hline $\begin{array}{l}\text { 6. I schedule a student conference and/or parent } \\
\text { conference. }\end{array}$ & 4.28 & A & 9.5 & 4.49 & A & 3 & 4.32 & A & 8 \\
\hline 7. I am always energetic and enthusiastic in class. & 4.34 & A & 7 & 4.33 & A & 9 & 4.34 & A & 7 \\
\hline 8. I pay a lot of attention to my work. & 4.47 & A & 4 & 4.42 & A & 7 & 4.46 & A & 4 \\
\hline $\begin{array}{l}\text { 9. I build a good working relationship with my } \\
\text { colleagues. }\end{array}$ & 4.56 & SA & 2.5 & 4.57 & SA & 2 & 4.56 & SA & 2 \\
\hline $\begin{array}{l}\text { 10. I listen attentively to student problems, } \\
\text { comments, and concerns. }\end{array}$ & 4.59 & SA & 1 & 4.61 & SA & 1 & 4.60 & SA & 1 \\
\hline Average Weighted Mean & 4.43 & A & & 4.37 & A & & 4.42 & A & \\
\hline
\end{tabular}

Table 7 shows the means of responses to teachers' engagement in terms of commitment. It can be gleaned from the composite mean that both of the respondents strongly agree that teachers uphold the school's vision, mission and core values with a composite mean of 4.59 , use appropriate teaching aids such as multi-media and other equipment, 4.54 , apply curricula that cater to the needs of the students, 4.53 , equip students with adequate knowledge and skills and enrich instructions by connecting them to real-life situation based on prescribed curriculum, 4.53 and maintain a classroom atmosphere conducive to learning by implementing effective classroom management styles, 4.51, ranked 1, 2, 3.5, 3.5 and 5, respectively. Moreover, both of the respondents agree that teachers apply different teaching methodologies that provide a variety of learning experience and productive educational activities with a composite mean of 4.44, participate in the outreach program and other community services of the school, 4.35 , provide quality education by applying the international standards of teaching, 4.31, upgrade their qualification by continuing education and participating in research and extension activities, 4.14 and join international, local and institutional civic and professional organizations for personal growth, 3.73. Comparing the responses of both groups, they agree on the teachers' engagement in terms of commitment with an average composite mean of 4.37. The responses of teachers obtained an average weighted mean of 4.35 while that of the administrators garnered 4.45. Teachers' responses revealed that they strongly agree that they uphold the school's vision, mission, and core values, with the highest weighted mean, while the same item obtained the 6th rank in the administrators' responses.

While, Table 8 shows the means of responses to teachers' engagement in terms of empowerment. It is shown in the composite mean that both respondents strongly agree that teachers read and keep up with the school announcements, memos and so on with a composite mean of 4.54 and accept accountability for my actions and their consequences, 4.51, ranked first and second respectively. On the other hand, both respondents agree that teachers respect and seek to use the perspective of others with a composite mean of 4.45, ranked 3rd, focus on solutions rather than on problems when they encounter work-related problems, 4.38, ranked 4th, work collaboratively with others in planning assignments, joint projects, and other school-related activities, 4.34, ranked 5th. More so, teachers and administrators agreed that teachers participate actively in staff development with a composite mean of 4.30 , participate in planning and conducting institutional programs or activities, 4.28, 
Alday, A.

deal with problems at work creatively, 4.27, attend in after-hours work events, 4.17 and involved in the decision-making pertaining to curriculum, 4.10 ranked 6th to 10th correspondingly. Comparing the responses of the two groups, both agree on the level of teachers' engagement in terms of empowerment with an average composite mean of 4.33. Average weighted mean obtained for the teachers' responses was 4.31 , while that of the administrators was 4.45 .

Table 7

Teachers' engagement in terms of commitment

\begin{tabular}{|c|c|c|c|c|c|c|c|c|c|}
\hline \multirow{2}{*}{ Responsibility } & \multicolumn{3}{|c|}{$\mathrm{T}$} & \multicolumn{3}{|c|}{ A } & \multicolumn{3}{|c|}{$\begin{array}{l}\text { Composite } \\
\text { Mean }\end{array}$} \\
\hline & WM & DI & $\mathrm{R}$ & WM & DI & $\mathrm{R}$ & $\mathrm{CM}$ & DI & $\mathrm{R}$ \\
\hline $\begin{array}{l}\text { 1. I uphold the school's vision, mission and core } \\
\text { values. }\end{array}$ & 4.61 & SA & 1 & 4.48 & $\mathrm{~A}$ & 6 & 4.59 & SA & 1 \\
\hline $\begin{array}{l}\text { 2. I apply curricula that cater to the needs of the } \\
\text { students. }\end{array}$ & 4.55 & SA & 2 & 4.45 & A & 7 & 4.53 & SA & 3.5 \\
\hline $\begin{array}{l}\text { 3. I provide quality education by applying the } \\
\text { international standards of teaching. }\end{array}$ & 4.32 & A & 7 & 4.25 & A & 9 & 4.31 & A & 8 \\
\hline $\begin{array}{l}\text { 4. I use appropriate teaching aids such as } \\
\text { multi-media and other equipment. }\end{array}$ & 4.53 & SA & 3.5 & 4.58 & SA & 3 & 4.54 & SA & 2 \\
\hline $\begin{array}{l}\text { 5. I apply different teaching methodologies that } \\
\text { provide a variety of learning experience and } \\
\text { productive educational activities. }\end{array}$ & 4.40 & A & 6 & 4.64 & SA & 1 & 4.44 & A & 6 \\
\hline $\begin{array}{l}\text { 6. I equip students with adequate knowledge and } \\
\text { skills and enrich instructions by connecting them to } \\
\text { a real-life situation based on a prescribed } \\
\text { curriculum. }\end{array}$ & 4.53 & SA & 3.5 & 4.54 & SA & 4 & 4.53 & SA & 3.5 \\
\hline $\begin{array}{l}\text { 7. I maintain a classroom atmosphere conducive to } \\
\text { learning by implementing effective classroom } \\
\text { management styles. }\end{array}$ & 4.50 & SA & 5 & 4.52 & SA & 5 & 4.51 & SA & 5 \\
\hline $\begin{array}{l}\text { 8. I upgrade my qualification by continuing } \\
\text { education and participating in research and } \\
\text { extension activities. }\end{array}$ & 4.08 & A & 9 & 4.39 & A & 8 & 4.14 & A & 9 \\
\hline $\begin{array}{l}\text { 9. I join international, local and institutional civic } \\
\text { and professional organizations for personal growth. }\end{array}$ & 3.65 & A & 10 & 4.07 & A & 10 & 3.73 & A & 10 \\
\hline $\begin{array}{l}\text { 10. I participate in the outreach program and other } \\
\text { community services of the school. }\end{array}$ & 4.30 & A & 8 & 4.61 & SA & 2 & 4.35 & A & 7 \\
\hline Average Weighted Mean & 4.35 & A & & 4.45 & A & & 4.37 & A & \\
\hline
\end{tabular}

Table 8

Teachers' engagement in terms of empowerment

\begin{tabular}{|c|c|c|c|c|c|c|c|c|c|}
\hline \multirow[t]{2}{*}{ Responsibility } & \multicolumn{3}{|c|}{$\mathrm{T}$} & \multicolumn{3}{|c|}{ A } & \multicolumn{3}{|c|}{$\begin{array}{l}\text { Composite } \\
\text { Mean }\end{array}$} \\
\hline & WM & DI & $\mathrm{R}$ & WM & DI & $\mathrm{R}$ & $\mathrm{CM}$ & DI & $\mathrm{R}$ \\
\hline 1. I attend in after-hours work events. & 4.14 & A & 9 & 4.32 & A & 10 & 4.17 & A & 9 \\
\hline 2. I participate actively in staff development. & 4.28 & A & 6 & 4.39 & A & 8 & 4.30 & A & 6 \\
\hline $\begin{array}{l}\text { 3. I work collaboratively with others in planning } \\
\text { assignments, joint projects, and other school-related } \\
\text { activities. }\end{array}$ & 4.30 & A & 5 & 4.49 & A & 4 & 4.34 & A & 5 \\
\hline $\begin{array}{l}\text { 4. I accept accountability for my actions and their } \\
\text { consequences. }\end{array}$ & 4.50 & SA & 2 & 4.52 & SA & 2 & 4.51 & SA & 2 \\
\hline $\begin{array}{l}\text { 5. I focus on solutions rather than on problems } \\
\text { when I encounter work-related problems. }\end{array}$ & 4.37 & A & 4 & 4.42 & A & 6 & 4.38 & A & 4 \\
\hline 6. I deal with problems at work creatively. & 4.25 & A & 7 & 4.36 & A & 9 & 4.27 & A & 8 \\
\hline $\begin{array}{l}\text { 7. I respect and seek to use the perspective of } \\
\text { others. }\end{array}$ & 4.44 & A & 3 & 4.51 & SA & 3 & 4.45 & A & 3 \\
\hline $\begin{array}{l}\text { 8. I participate in planning and conducting } \\
\text { institutional programs or activities. }\end{array}$ & 4.24 & A & 8 & 4.46 & A & 5 & 4.28 & A & 7 \\
\hline $\begin{array}{l}\text { 9. I read and keep up with the school } \\
\text { announcements, memos and so on. }\end{array}$ & 4.54 & SA & 1 & 4.57 & SA & 1 & 4.54 & SA & 1 \\
\hline $\begin{array}{l}\text { 10. I am involved in the decision-making pertaining } \\
\text { to curriculum. }\end{array}$ & 4.03 & A & 10 & 4.41 & A & 7 & 4.10 & A & 10 \\
\hline Average Weighted Mean & 4.31 & A & & 4.45 & A & & 4.33 & A & \\
\hline
\end{tabular}




\subsection{Relationship between professional profile and organizational citizenship behavior}

Table 9 shows the significant relationship between the respondents' professional profile and organizational citizenship behavior. It can be inferred that there is a significant relationship between school affiliation and OCB with the chi-square value of 354.247 and $p$-value of .000 . Thus, rejecting the null hypothesis. When it comes to employment status and OCB, the chi-square value was 18.750 and the $p$-value obtained was .538, which implies that the null hypothesis shall be failed to reject and that there is no significant relationship between the two variables. Looking at the significant relationship between the length of service and OCB, a chi-square value of 78.118 and $p$-value of .948 was computed. The researcher failed to reject the null hypothesis which pertains to having no significant relationship between the variables. A chi-square value of 72.891 and a $p$-value of .701 was obtained on the relationship between the highest degree earned and OCB. Null hypothesis shall be accepted and it may be inferred that there is no significant relationship between the highest degree earned and OCB.

\section{Table 9}

Relationship between professional profile and organizational citizenship behavior

\begin{tabular}{lcccc}
\hline \multicolumn{1}{c}{ Professional Profile } & $\mathrm{X}^{2}$ value & $p$-value & Decision & DI \\
\hline School Affiliation & 354.247 & .000 & Reject Ho & Significant \\
Employment Status & 18.750 & .538 & Fail to Reject Ho & Not Significant \\
Length of Service & 78.118 & .948 & Fail to Reject Ho & Not Significant \\
Highest Degree Earned & 72.891 & .701 & Fail to Reject Ho & Not Significant \\
\hline
\end{tabular}

Table 10 shows the significant relationship between the respondents' professional profile and teachers' engagement. It can be inferred that there is a significant relationship between school affiliation and teachers' engagement with the chi-square value of 394.609 and $p$-value of .000 . Thus, rejecting the null hypothesis. When it comes to employment status and teachers' engagement, the chi-square value was 19.536 and the $p$-value obtained was .551, which implies that the null hypothesis shall be failed to reject and that there is no significant relationship between the two variables. Looking at the significant relationship between the length of service and engagement, a chi-square value of 89.269 and $p$-value of .864 was computed. The result fails to reject the null hypothesis which pertains to having no significant relationship between the variables. A chi-square value of 74.170 and a $p$-value of .770 was obtained on the relationship between the highest degree earned and engagement, thus failing to reject the null hypothesis. It may be inferred that there is no significant relationship between the highest degree earned and teachers' engagement.

\section{Table 10}

Relationship between professional profile and teachers' engagement

\begin{tabular}{lcccc}
\hline \multicolumn{1}{c}{ Professional Profile } & $\mathrm{X}^{2}$ value & $p$-value & Decision & DI \\
\hline School Affiliation & 394.609 & .000 & Reject Ho & Significant \\
Employment Status & 19.536 & .551 & Fail to Reject Ho & Not Significant \\
Length of Service & 89.269 & .864 & Fail to Reject Ho & Not Significant \\
Highest Degree Earned & 74.170 & .770 & Fail to Reject Ho & Not Significant \\
\hline
\end{tabular}

\section{Discussion}

\subsection{Organizational citizenship behavior}

Looking closely at the result of teachers' OCB in terms of responsibility, it may be gleaned that the ranks of the two groups of respondents are very much parallel. Both seem to strongly agree that teachers should respond to students with respect, even in a difficult situation. According to Serrano and Flores (2016), responsibility is an obligation to do something with the expectation that some act or output will result. In this light, the two groups believe that the teachers respond to certain tasks assigned to them which are expected to be done, even though a difficult situation may arise. Both groups seem to agree in the last ranking item that the teachers have a sense of volunteerism for roles and tasks that are not part of my job. Even though responsibility entails finishing a work 
Alday, A.

that is expected out of an individual, responsibility may also entail volunteering for tasks that are beyond the call of duty.

On the assessment of teachers' OCB in terms of personal discipline, comparing the results closely may reveal that the self-assessment of the teachers were validated by their administrators since the ranking and mean values do not have a significant discrepancy. Both groups seem to strongly agree that the teachers should maintain a professional manner at all times and are aware that they should keep confidential information concerning students, colleagues and the school. The personal discipline exemplified by the teachers connotes conduct, which is described by Bueno (2016) as a good behavior expected to all staff within the organization.

In the responses of both the teachers and administrators in terms of handling work stress, they believe that they adjust well in terms of the physical working environment, which may be taken on a positive note. A conducive physical working environment like lighting, space, equipment, etc. contributes to the employees' organizational citizenship behavior in terms of work stress. According to Pereda (2014), in maintaining a productive level of stress, individuals must be challenged, active and growing without being pressured beyond their ability to cope. It was also suggested by Pereda (2014) that the following operating system could be programmed by managers to improve stress management in the organization: redesign individual task, create a better work schedule, improve physical characteristics of the work, and implement training, counseling, physical fitness, and team building programs.

Responses of both groups have slight discrepancies in terms of ranking. The two groups of respondents, however, strongly agree that the teachers are willing to help others who have work-related and personal problems. Teachers are aware that teaching is service. They entered the profession in the hope that they could help influence the students to become better persons and live a more meaningful life. Being the second parents of the students, teachers should take the best interest of the students as their credo. These students have been entrusted to them and therefore should be treated with love, care, and compassion. They should provide a caring commitment where the students would feel valued and accepted. Teachers should show positive influence and empathy in dealing with the students. This will strengthen the bond between the teacher and student (Lim, Casilihan, \& Caubic, 2014). Teachers helping students is one of the tasks which is not usually part of their job description, but is nonetheless expected to be seen in them. But teachers helping their colleagues should be seen in a different light. With the work stress confronting them every day, they almost have no time for their families and friends, let alone time to help their colleagues in their work-related and personal problems. But in the table, it may be seen that the respondents are willing to help others, not only their students, when it comes to solving their problems, parallel to what Lim et al. (2014) noted.

Both groups of respondents strongly agree that the teachers are proud to tell others that they are part of their organization. They have a sense of belongingness and they are proud to be an identified part of their institution. Noe et al. (2015) defines organizational commitment as the degree to which an employee identifies with the organization and is willing to put forth effort on its behalf. Individuals who feel they have been unjustly treated by their employers often respond by reducing their level of commitment and are often looking for the first good chance to quit their jobs. Looking at the respondents' answers, it could be inferred that the teachers have a strong organizational commitment, judging on their identification with the organization. It may also be an implication of the administrators' fair and humane treatment since if they were treated otherwise, they will not yield a high weighted mean for organizational commitment. The result was also confirmed by the study of Maestro (2015) that OCB level, moderately exceeds formal job responsibility, high level of affective commitment and low level for turnover intention.

\subsection{Teachers' engagement}

Turning on the result of teachers' engagement in terms of job satisfaction, some items have discrepancies in the rankings. However, both groups strongly agree that the teachers listen attentively to student problems,

22 Consortia Academia Publishing (A partner of Network of Professional Researchers and Educators) 
comments, and concerns. Noe et al. (2015) may explain that job satisfaction is a function of values and perception, of what a person consciously or unconsciously desires to obtain. Job satisfaction may also depend on the intrinsic and extrinsic motivation of an employee. But mostly, job satisfaction entails one's values. Listening to students' concerns and comments means that they value other people's struggles and stories more than the grades and achievements of their students.

The result on teachers' engagement in terms of commitment is somehow related to the study of Hernandez (2017) which revealed that most of the respondents who agree that they have a high sense of belongingness to their organization, are often very proud of the work that they do. Also, Maninang (2015) on his study revealed that the employees are engaged, which means they are vigorous and dedicated to their work, and emotionally committed to their organization that they stay connected to it for a longer period of time and evidently possessed the willingness to put extra effort on their work. This is also relevant to the concept of Bueno (2016) of personal commitment to work which means the total sacrifice that personnel have to make to ensure the attainment of the organization's basic objectives.

Commitment to the teaching profession may mean that teachers possess values that are aligned with the school's vision, mission and core values. Otherwise, they will find themselves lost and unsatisfied because the intrinsic motivations are not met. The administrators' responses reveal that they strongly agree that the teachers apply different teaching methodologies that provide a variety of learning experiences and productive educational activities, while the same statement ranked 6th the teachers' responses. This implies higher productivity. According to Noe et al. (2015), employees who are engaged in their work and committed to the company they work for, give companies a competitive advantage, including higher productivity, better customer service, and lower turnover. Higher productivity is a result of high work engagement and commitment. Teachers who are committed to their chosen vocation does not only teach for the sake of teaching, but also to inspire other people's lives and to understand that in every lesson, the school's mission, vision and core values should be integrated.

In terms of empowerment, both groups agree that teachers possess work engagement. Specifically, the teachers and administrators both strongly agree that the teachers read and keep up with the school announcements, memos and so on. According to Newstrom (2015), empowerment authorizes employees to cope with situations and enables them to take control of problems as they arise. With the teachers striving to become up to date on the recent school announcements and memos, they largely help themselves to be empowered by coping with different kinds of situation and accepting problems that may arise, yet they are confident that they can cope up with the difficulties.

\subsection{Relationship between professional profile and organizational citizenship behavior}

There is a significant relationship between the school affiliation and organizational citizenship, since this involves how the person feels about the institution itself. It involves the persons inside the organization, the differences and the culture that may vary from school to school. The school environment can influence the teachers' involvement in prosocial activities if the school promotes the concepts of connectedness and cooperation. For the school environment, the first and most important scheme is the cultivation of prosocial involvement as a kind of school culture (Lam, 2012). Individual acts of citizenship can be facilitated by an organizational culture that specifically encourages "going the extra mile," direct rewards for such actions, jobs that provide satisfaction, supportive leadership that demonstrates caring and trust, flexible and family-friendly workplace benefits and personal examples set by managers at all levels (Newstrom, 2015).

However, their employment status, length of service and highest degree earned do not dictate their level of OCB. It may not follow that regular employees will "go the extra mile" for other people. This is in contrast to the study of Damir (2015) that teachers' job status has a statistically significant effect on organizational citizenship behaviors. Also, Akbar et al. (2019) on his study of IT environment revealed that a significant relationship exists between employment status and service oriented OCB. Meanwhile, a tenured employee may not be guaranteed 
Alday, A.

to be as helpful as that employee who has just started working in the institution. Results from the study of Hayag (2017) confirmed that demographic profile such as years of service and organizational citizenship behavior is not significantly correlated. This may be explained by the study of Avci (2016) which found out those opinions on the organizational citizenship behaviors vary significantly in terms of the respondents' professional seniority.

Also, it is clearly shown in the result that a doctorate degree does not come with altruism, which are helpful behaviors directed toward individuals or groups within the organization. According to Zarate (2012), organizational citizenship behavior is a behavior above and beyond the call of duty. There may be other factors such as personal attitudes and self-efficacy. In relation to what Riggio (2017) said that certain personality types, particularly persons who are "agreeable and conscientious employees are more likely to perform OCBs. On the contrary, the study of Saleem, Nisar, and Imran (2017) and Mahnaz, Mehdi, Jafar, and Abbolghasem (2013) found out that education and job experience are significantly associated with OCB.

\subsection{Relationship between professional profile and teachers' engagement}

School affiliation has a significant relationship with work engagement. According to Riggio (2017), being recognized and rewarded for one's accomplishments and working in an organization that treats people fairly, all contribute to employee engagement. Hence, the culture of the school may be a factor in such behavior. This is supported by the study of Kilonzo, Were, and Odhiambo (2018) which shows that organizational culture influence work engagement. The study of Shuck, Rocco, and Albornoz (2011) reveals that culture of fairness and support show a positive effect on work engagement. This is also parallel to the findings of Welch (2011) which conclude that environment and interaction (communication) can create work engagement.

However, it was seen that employment status, length of service and highest degree earned have no significant relationship with work engagement. This is somehow relevant to the findings of Madan and Srivastava (2015), Chaudhary and Rangnekar (2017). Positive attitudes of people, let alone the teachers, do not come with a high degree, tenure or a permanent employment status. It may mean that apart from the good leadership present in the schools, other factors do not really contribute to the high work engagement of the teachers. It is something they already possess and is developed through their commitment in their respective organizations. More so, the result of the study of Schweitzer (2014) showed that work-related resources are the strongest predictor of work engagement.

In contrast, the study of Sharma, Goel, and Sengupta (2017) found out that work engagement has a positive relationship with education and length of experience. More so, Shukla et al. (2015), reported that senior employees were more engaged than employees with less tenure. The study of Sharma and Gangwani (2017) confirmed that there is a significant difference in the level of engagement in terms of years of experience.

\section{Conclusion}

Teachers affirm that they possess OCB and engagement and administrators are also convinced of such behaviors. This implies that teachers are very much aware of their responsibility with the students as well as with the institution. Hence, they also display a high personal discipline and commitment to teaching as well as to the organization. It is also revealed that school affiliation relates to teachers' OCB and engagement. However, employment status, length of service, and highest degree earned are not determinants of teachers' OCB and engagement. Thus, the school administrators and human resource managers may consider developing programs that may enhance the prosocial behavior and engagement of teachers to fully contribute to the school's vision and mission. They may also consider cultivating other factors such as teachers' morale and resiliency and the administrators' practice of empowerment.

In the light of the findings, this paper has its own limitations. First, the researcher diverted from the common dimensions of OCB and engagement. Second, the researcher made use of a self-made questionnaire and did not go through a reliability test. Lastly, the result is limited to the answers of the respondents who returned the 
questionnaire.

\section{References}

Abed, F., \& Elewa, A. H. (2016). The relationship between organizational support, work engagement and organizational citizenship behavior as perceived by staff nurses at different hospitals. IOSR Journal of Nursing and Health Science, 5(4), 113-123.

Agong, H. M., \& Montalbo, A. F. (2017). Employee engagement and areas of work life of call center agents in the Philippines. International Letters of Social and Humanistic Sciences, 77, 44-55. https://doi.org/10.18052/www.scipress.com/ILSHS.77.44

Akbar, M. I., Karim, T. A., Abbas, H. W., Saleem, M. F., Moinud-Din, N., \& Aslam, U. (2019). Impact of employment status on service oriented OCB: Intervening roles of job satisfaction and organizational commitment in information technology environment. International Journal of Computer Science and Network Security, 19(4), 163-168.

Alarcon, G. M., \& Lyons, J. B. (2011). The relationship of engagement and job satisfaction in working samples. The Journal of Psychology, 145, 463-480. https://doi.org/10.1080/00223980.2011.584083

Apruebo, R. (2009). Introductory social psychology. Educational Publishing House.

Ariani, D. W. (2014). Relationship leadership, employee engagement and organizational citizenship behavior. International Journal of Business and Social Research, 4(8), 74-90.

Avci, A. (2016). Investigation of teachers' perceptions of organizational citizenship behavior and their evaluation in terms of educational administration. Educational Research and Reviews, 11(7), 318-327. https://doi.org/10.5897/ERR2016.2641

Balyer, A., Ozcan, K., \& Yildiz, A. (2017). Teacher empowerment: School administrators' roles. Eurasian Journal of Educational Research, 17(70), 1-18. https://doi.org/10.14689/ejer.2017.70.1

Bay, A., An, I., \& Laguador, J. (2014). Organizational satisfaction and work engagement of Filipino teachers in an Asian university. International Journal of Multidisciplinary Academic Research, 2(4), 32-41.

Buenaventura, D. (2013). Turn-over rate of teachers in private basic education schools: Input to administrative program development. https://doi.org/10.13140/RG.2.2.13895.14249

Bueno, D. C. (2016). Theory and practice of human resource management (a modular approach). Great Books Trading.

Chaudhary, R., \& Rangnekar, S. (2017). Socio-demographic factors, contextual factors, and work engagement: evidence from India. Emerging Economy Studies, 3(1), 1-18. https://doi.org/10.1177/2394901517696646

Choochom, O. (2016). A causal relationship model of teachers' work engagement. International Journal of Behavioral Science, 11(2), 143-152.

Colella, A., \& Hitt, M. (2015). Organizational behavior ( $4^{\text {th }}$ ed). John Wiley \& Sons, Inc.

Collie, R. J., Shapka, J. D., \& Perry, N. E. (2011). Predicting teacher commitment: The impact of school climate and social-emotional learning. Psychology in the Schools, 48, 1034-1048. https://doi.org/10.1002/pits.20611

Dela Cruz, R. (2016). Attrition of private and public school teachers: A comparative analysis. Advances in Social Research, 2(1), 29-32.

Demir, K. (2015). Teachers' organizational citizenship behaviors and organizational identification in public and private preschools. Procedia-Social and Behavioral Sciences, 174, 1176-1182. https://doi.org/10.1016/j.sbspro.2015.01.734

Di Paola, M., \& Neves, P. (2009). Organizational citizenship behaviors in American and Portuguese public schools, measuring the construct across cultures. Journal of Educational Administration, 47(4), 490-507. https://doi.org/10.1108/09578230910967464

Ditan, C. D. (2016). Understanding and managing organizational behavior. Anvil Publishing, Inc.

Farooqui, M. R. (2012). Measuring organizational citizenship behavior as a consequence of organizational climate. Asian Journal of Business Management, 4(3), 294-302. 
Alday, A.

Field, L. K., \& Buitendach, J. H. (2012). Work engagement, organizational commitment, job resources and job demands of teachers working within disadvantaged high schools in KwaZulu-Natal, South Africa. Journal of Psychology in Africa, 22(1), 87-95. https://doi.org/10.1080/14330237.2012.10874525

Gaddis, A. K. (2016).Teacher organizational citizenship behavior and principal emotional intelligence: How they relate and interact. Unpublished dissertation, University of Kansas, Lawrence, Kansas.

Green P. I. Jr., Finkel, E. J., Fitzsimons, G. M., \& Gino F. (2017). The energizing nature of work engagement: Toward a new need-based theory of work motivation. Research in Organizational Behavior, 37, 1-18. https://doi.org/10.1016/j.riob.2017.10.007

Hayag, S. C. (2017). Demographic profile, organizational citizenship behavior and work values of Filipino customer service representatives. Unpublished masteral thesis, University of Santo Tomas, Manila, Philippines.

Hernandez, K. D. (2017). Ethical leadership, work engagement and organizational commitment of employees from Department of Environment and Natural Resources. Unpublished masteral thesis, University of Santo Tomas, Manila, Philippines.

Ibukunoluwa, O. E., Anuoluwapo, A. G., \& Agbude, G. A. (2015). Benefits of organizational citizenship behaviours for individual employees. Covenant International Journal of Psychology, 1(1), 56-57.

Kilonzo, T. M., Were, S., \& Odhiambo, R. (2018). Influence of employee engagement on the performance of teachers in secondary schools in Machakos country in Kenya. International Journal of Novel Research in Humanity and Social Sciences, 5(1), 52-71.

Kónya, V., Matić, D., \& Pavlović, J. (2016). The influence of demographics, job characteristics and characteristics of organizations on employee commitment. Acta Polytechnica Hungarica, 13(3), 119-138.

Kozlowski, S. W. J. (2012). The oxford hand book of organizational psychology. Oxford University Press, Inc. https://doi.org/10.1093/oxfordhb/9780199928309.013.0001

Krastev, I. D., \& Stanoeva, G. V. (2013). Organizational citizenship behavior and satisfaction with coworkers among Bulgarian teaching staff. Baltic Journal of Career Education and Management, 1(1), 40-47.

Lam, C. M. (2012). Prosocial involvement as a positive youth development construct: A conceptual review. The Scientific World Journal, 12, 1-8. https://doi.org/10.1100/2012/769158

Landy, F., \& Conte, M. (2010). Work in the 21st century: An introduction to industrial and organizational psychology ( $3^{\text {rd }}$ ed.).Wiley \& Sons.

Lim, L. S., Casilihan, L. L., \& Caubic, R. A. (2014). The teaching profession. Adriana Publishing Co., Inc.

Madan, P., \& Srivastava, S. (2015). Socially responsible investing: An emerging concept in investment management. FIIB Business Review, 4(2), 53-62. https://doi.org/10.1177/2455265820150210

Maestro, P. M. (2015). Organizational citizenship behavior, organizational commitment and turnover intention of teaching staff at Culiat high school. Unpublished masteral thesis, University of Santo Tomas, Manila, Philippines.

Mahnaz, M. A., Mehdi, M., Jafar, K. M., \& Abbolghasem, P. (2013). The effect of demographic characteristics on organizational citizenship behavior in the selected teaching hospitals in Tehran. African Journal of Business Management, 7(34), 3324-3331. https://doi.org/10.5897/AJBM2013.7117

Malipot, M. (2018, June 16). Teacher migration from private to public schools is a problem. The Manila Times. https://news.mb.com.ph/2018/06/16/teacher-migration-from-private-to-public-schools-is-a-problem

Maninang, M. I. C. (2015). Employee engagement, organizational commitment and citizenship behavior: basis of organizational health program. Unpublished masteral thesis, University of Santo Tomas, Manila, Philippines.

Mateo, J. (2018, August 23). Pay salary of private school teachers, gov't urged. The Philippine Star. https://www.philstar.com/other-sections/education-and-home/2018/08/23/1844947/pay-salary-private-sc hool-teachers-govt-urged

McShane, V. G. (2012). Organizational behavior: Emerging knowledge, global reality (6 ${ }^{\text {th }}$ ed.). USA: McGraw-Hill.

Menteşe, S., Üstün, A., \& Doğruöz, S. (2013). An evaluation of the effects of teacher employment under 
Organizational citizenship behavior and teachers' engagement in Unified Schools of the Archdiocese of Lipa

different statuses on the levels of teachers' organizational commitment: A case in Amasya. The International Journal of Research in Teacher Education, 4(1), 41-62.

Muchinsky, P. M., \& Culbertson, S. S. (2016). Psychology applied to work: An introduction to industrial and organizational psychology. Hypergraphic Press.

Newstrom, J. W. (2015). Organizational behavior: Human behavior at work. McGraw-Hill Education.

Noe, R., Hollenbeck, J., Gerhart, B., \& Wright, P. (2015). Human resource management (9 ${ }^{\text {th }}$ ed). McGraw Hill Education.

Pacleb, L. K. T. (2016). Psychological capital and organizational citizenship behavior as predictors of employee engagement in Shakey's pizza restaurant. Unpublished masteral thesis, University of Santo Tomas, Manila, Philippines.

Pereda, P. R., \& Pereda, P. P. (2014). Principles of management and organization. Mindshapers Co.

Pila, R. (2013). The teaching profession in the Philippines. Anvil Publishing.

Qadeer, F., Ahmad, A., Hameed, I., \& Mahmood, S. (2016). Linking passion to organizational citizenship behavior and employee performance: The mediating role of work engagement. Pakistan Journal of Commerce and Social Sciences, 10(2), 316-334.

Riggio, R. (2017). Introduction to industrial/organizational psychology ( $7^{\text {th }}$ ed.). Routledge. https://doi.org/10.4324/9781315620589

Salansan, E. (2011). Work-life programs and organizational commitment. Philippine Daily Inquirer. https://business.inquirer.net/2298

Saleem, A., Nisar, Q., \& Imran, A. (2017). Organization citizenship behaviour, psychological empowerment and demographic characteristics: Teachers' perspective. International Journal of Advanced and Applied Sciences, 4(7), 129-135. https://doi.org/10.21833/ijaas.2017.07.019

Schweitzer, M. J. (2014). Predictors of work engagement among teachers in Regina and Saskatoon. Masteral thesis, University of Regina, Saskatchewan, Canada.

Serrano, A. C., \& Flores, M. F. (2016). Management in human behavior in an organization. Manila: Unlimited Books Library Services \& Publishing Inc.

Sesen, H., Cetin, F., \& Basim, H. N. (2011). The effect of burnout on organizational citizenship behaviour: The mediating role of job satisfaction. International Journal of Contemporary Economics and Administrative Sciences, 1(1), 40-64.

Sharma, A., Goel, A., \& Sengupta, S. (2017). How does work engagement vary with employee demography? -revelations from the Indian IT industry. Procedia Computer Science, 122, 146-153. https://doi.org/10.1016/j.procs.2017.11.353

Sharma, S., \& Gangwani. S. (2017). The impact of demographic variables on employee engagement in public and private service sector in India. International Journal of Research in Economics and Social Sciences, 7(5), 299-313.

Shrestha, M., \& Subedi, D. (2020). Organizational citizenship behavior among teachers of Nepal: Did locale contribute it's in school settings? American Journal of Economics and Business Management, 3(1), 1-23. https://doi.org/10.33215/sjom.v3i3.298

Shuck, M. B., Rocco, T. S., \& Albornoz, C. A. (2011). Exploring employee engagement from the employee perspective: implications for HRD. Journal of European Industrial Training, 35(4), 300-325. https://doi.org/10.1108/03090591111128306

Shukla, S., Adhikari, B., \& Singh, V. (2015). Employee engagement-role of demographic variables and personality factors. Amity Global HRM Review, 5, 65-73.

Sokolov, C.K. (2017). Teacher engagement in grades 4-8. Theses \& Dissertation. https://digitalcommons.pepperdine.edu/etd/779

Somech, A., \& Oplatka, I. (2014). Organizational citizenship behavior in schools: Examining the impact and opportunities within educational systems. Routledge. https://doi.org/10.4324/9781315866956

Supriadi, Y. N., Ahman, E., Wibowo, L. A., \& Furqon, C. (2019). Organizational citizenship behavior model for turnover intention management. International Journal of Recent Technology and Engineering, 8(2), 340-347. 
Alday, A.

Welch, M. (2011). The evolution of the employee engagement concept: Communication implications. Corporate Communications: An International Journal, 16(4), 328-346. https://doi.org/10.1108/13563281111186968

Wesley, R. \& Krishnan, G. (2013). Correlates employee engagement with turnover intention. Intercontinental Journal of Human Resource Research Review, 1(9), 53-62.

Zarate, C. A. (2016). Organizational behavior and management in the Philippine organizations. Rex Printing Company. 